\title{
Propofol inhibits cyclo-oxygenase activity in human monocytic THP-1 cells
}

\section{Le propofol inhibe l'activité de la cyclo-oxygénase dans les cellules monocytaires humaines THP-1}

\author{
Takefumi Inada, MD · Kozue Kubo, MD • \\ Tomoko Kambara, MD $\cdot$ Koh Shingu, MD
}

Received: 14 August 2008/Revised: 26 November 2008/ Accepted: 9 December 2008/Published online: 28 January 2009

(C) Canadian Anesthesiologists' Society 2009

\begin{abstract}
Purpose Monocytes/macrophages are key players in innate and adaptive immunity. Upon stimulation, they secrete prostanoids, which are produced by cyclooxygenase from arachidonic acid. Prostanoids influence inflammation and immune responses. We investigated the effect of propofol on prostaglandin $E_{2}$ and thromboxane $B_{2}$ production by the human monocytic cell line THP-1.

Methods The THP-1 cells were cultured with lipopolysaccharide $\left(1 \mu \mathrm{g} \mathrm{ml}^{-1}\right)$ in the presence of clinically relevant sedative/anesthetic concentrations of propofol $(0-30 \mu M)$ for $18 \mathrm{~h}$, and the concentration of prostaglandin $E_{2}$ and thromboxane $B_{2}$ in culture supernatants was measured using an enzyme immunoassay. Intracellular cyclooxygenase protein expression was measured by flow cytometry. Cyclooxygenase activity was assessed by measuring production of prostaglandin $E_{2}$ and thromboxane $B_{2}$ by THP-1 cells after arachidonic acid $(10 \mu M)$ substrate provision.

Results Propofol decreased the production of prostaglandin $E_{2}\left(75.4 \pm 6.4 \mathrm{pg} \mathrm{ml}^{-1}\right.$ at $0 \mu \mathrm{M}$ vs. $28.5 \pm 11.2$ pg ml ${ }^{-1}$ at $\left.30 \mu \mathrm{M} ; \quad P<0.001\right)$ and thromboxane $B_{2}$ $\left(282.4 \pm 79.2 \mathrm{pg} \mathrm{ml}^{-1}\right.$ at $0 \mu \mathrm{M}$ vs. $40.4 \pm 21.7 \mathrm{pg} \mathrm{ml}^{-1}$ at $30 \mu M ; P<0.001)$. The inhibition was not due to the decreased cyclooxygenase protein expression because intracellular staining of this enzyme was not affected by propofol. After arachidonic acid provision, prostaglandin $E_{2}$ and thromboxane $B_{2}$ production from activated THP-1 cells was significantly $(P<0.001)$ decreased with
\end{abstract}

T. Inada, MD $(\bowtie) \cdot$ K. Kubo, MD · T. Kambara, MD . K. Shingu, MD

Department of Anesthesiology, Kansai Medical University, 10-15, Fumizono-cho, Moriguchi, Osaka 570-8507, Japan e-mail: nvkc20988@hera.eonet.ne.jp propofol, indicating direct suppression of cyclooxygenase activity with propofol.

Conclusions Propofol may modulate inflammation via the suppression of cyclooxygenase activity. Through the inhibition of prostanoid production, propofol may enhance immune responses.

\section{Résumé}

Objectif Les monocytes / macrophages sont des acteurs importants de l'immunité innée et adaptative. Lorsqu'ils sont stimulés, ils sécrètent des prostanoïdes, lesquels sont produits par la cyclo-oxygénase à partir de l'acide arachidonique. Les prostanoïdes, quant à eux, jouent un rôle dans l'inflammation et les réponses immunitaires. Nous avons évalué l'effet du propofol sur la production de prostaglandine $E_{2}$ et de thromboxane $B_{2}$ dans la lignée cellulaire monocytaire humaine THP-1.

Méthode Les cellules THP-1 ont été cultivées avec du lipopolysaccharide $\left(1 \mu \mathrm{g} \cdot \mathrm{ml}^{-1}\right)$ en présence de concentrations anesthésiques / sédatives cliniquement pertinentes de propofol $(0-30 \mu \mathrm{M})$ pendant $18 \mathrm{~h}$, et la concentration de prostaglandine $E_{2}$ et de thromboxane $B_{2}$ dans les surnageants de la culture a été mesurée à l'aide d'un dosage séro-immunologique enzymatique. L'expression protéinique de la cyclo-oxygénase intracellulaire a été mesurée par cytométrie en flux. L'activité de la cyclo-oxygénase a été évaluée en mesurant la production de prostaglandine $E_{2}$ et de thromboxane $B_{2}$ par les cellules THP-1 en présence d'un substrat d'acide arachidonique $(10 \mu \mathrm{M})$.

Résultats Le propofol a réduit la production de prostaglandine $E_{2}\left(75,4 \pm 6,4 \mathrm{pg} \cdot \mathrm{ml}^{-1}\right.$ à $0 \mu M$ vs. $28,5 \pm$ $11,2 \mathrm{pg} \cdot \mathrm{ml}^{-1}$ à $\left.30 \mu \mathrm{M} ; \mathrm{P}<0.001\right)$ et de thromboxane $B_{2} \quad\left(282,4 \pm 79,2 \mathrm{pg} \cdot \mathrm{ml}^{-1}\right.$ à $0 \mu M$ vs. $40,4 \pm 21,7$ $\mathrm{pg} \cdot \mathrm{ml}^{-1}$ à $\left.30 \mu \mathrm{M} ; \mathrm{P}<0.001\right)$. L'inhibition n'a pas été causée par l'expression protéinique réduite de la cyclo- 
oxygénase car la coloration intracellulaire de cette enzyme n'a pas été affectée par le propofol. Après l'addition d'un substrat d'acide arachidonique, la production de prostaglandine $E_{2}$ et de thromboxane $B_{2}$ à partir des cellules THP-1 activées a été significativement réduite $(P<0.001)$ avec le propofol, ce qui indique la suppression directe de l'activité de la cyclo-oxygénase par le propofol.

Conclusion Le propofol pourrait moduler la réponse inflammatoire en supprimant l'activité de la cyclo-oxygénase. En inhibant la production de prostanoïdes, le propofol pourrait améliorer les réponses immunitaires.

Propofol is an anesthetic frequently used when critically ill patients are sedated in the intensive care unit. ${ }^{1-3}$ Since these patients may already be immunosuppressed by preexisting diseases, surgical trauma, and/or overwhelming infection, ${ }^{4,5}$ even small adverse effects on immunity, due to the sedative, could be devastating for such patients.

Monocytes-macrophages are key effectors in the innate immune system. ${ }^{6}$ Macrophages also have a role in the adaptive immune system by presenting antigen peptides to T cells. ${ }^{6}$ After activation by bacterial products, monocytesmacrophages may produce numerous kinds of molecules, including cytokines, chemokines, nitric oxide, and oxygen radical species. ${ }^{6}$ Propofol is reported to down-regulate the production of pro-inflammatory cytokines, nitric oxide, and reactive oxygen intermediates. ${ }^{1,2,7-11}$ Prostanoids, including the prostaglandins and thromboxanes, are also produced by monocytes-macrophages, ${ }^{6,8,12-14}$ but the effect of propofol on the production of prostanoids by these cells is not well documented.

Cyclo-oxygenase (COX), also known as prostaglandin $\mathrm{H}_{2}\left(\mathrm{PGH}_{2}\right)$ synthase, is an essential enzyme in the conversion of arachidonic acid (AA) to $\mathrm{PGH}_{2}$, which is further converted by specific prostanoid syntheses into $\mathrm{PGD}_{2}$, $\mathrm{PGE}_{2}, \mathrm{PGF}_{2 \alpha}, \mathrm{PGI}_{2}$, and thromboxane $\mathrm{A}_{2}\left(\mathrm{TXA}_{2}\right) .{ }^{14,15}$ For example, $\mathrm{PGE}_{2}$ and $\mathrm{TXA}_{2}$, the major prostanoids produced by monocytes-macrophages, ${ }^{14}$ are produced from $\mathrm{PGH}_{2}$ by prostaglandin $\mathrm{E}_{2}$ synthase (PGES) and thromboxane $\mathrm{A}_{2}$ synthase (TXS), respectively. ${ }^{14,15}$ For AA production, it is produced by cleavage of membrane phospholipids by cytosolic phospholipase $\mathrm{A}_{2} \quad\left(\mathrm{cPLA}_{2}\right)$, whose activity is controlled via intracellular calcium and mitogen-activated protein kinases (MAPKs). ${ }^{16-18}$

The COX enzyme has two isoforms, COX-1 and COX2. COX-1 is constitutively expressed in nearly all tissues, including monocytes-macrophages and endothelial cells, and is responsible for producing the low levels of prostanoids necessary for normal physiological activity. ${ }^{14,15}$ On the other hand, COX-2 is an inducible enzyme and is up-regulated in response to various stimuli, such as cytokines and bacterial products. ${ }^{14,15}$ The expression of COX-2 in monocytes-macrophages is greatly increased at sites of inflammation and leads to the increased production of prostanoids. ${ }^{6}$

The aim of the present study was to evaluate propofol's effect on $\mathrm{PGE}_{2}$ and $\mathrm{TXA}_{2}$ production using the human monocytic cell line THP-1.

\section{Materials and methods}

Chemicals and proteins

The following chemicals and proteins were used: propofol (2,6-di-isopropylphenol) (Sigma-Aldrich); arachidonic acid (AA) and lipopolysaccharide (LPS; Escherichia coli 0111:B4) (St. Louis, MO, USA); SC-560 and NS-398 (Cayman Chemical, Ann Arbor, MI, USA); anti-COX-1 (AS70)-fluorescein isothiocyanate (FITC)/anti-COX-2 (AS67)-phycoerythrin (PE) antibody cocktail, and Annexin V-PE (BD Pharmingen, San Jose, CA, USA).

\section{Cell culture}

The THP-1 cells from the American Type Culture Collection (ATCC) were cultured at $37^{\circ} \mathrm{C}$ in $5 \% \mathrm{CO}_{2}$ in RPMI 1640 (Sigma) containing 2-mercaptoethanol $55 \mu \mathrm{M}$ (Gibco, Grand Island, NY, USA), penicillin $100 \mu \mathrm{g} \mathrm{ml}^{-1}$, and streptomycin $100 \mu \mathrm{g} \mathrm{ml}^{-1}$, and supplemented with $10 \%$ fetal calf serum (FCS) (endotoxin $<10.0 \mathrm{EU} \mathrm{ml}^{-1}$ ) (HyClone, Logan, UT, USA) (RPMI complete medium).

Effect of propofol on the production of $\mathrm{PGE}_{2}$ and $\mathrm{TXB}_{2}$ from THP-1 cells

THP- 1 cells $\left(5 \times 10^{6} / \mathrm{ml}\right)$ were either stimulated with LPS $1 \mu \mathrm{g} \mathrm{ml}^{-1}$ or left unstimulated in the absence [(dimethylsulfoxide) (DMSO)] or the presence of propofol 0-30 $\mu \mathrm{M}$. These concentrations encompass clinically pertinent sedative-anesthetic concentrations. ${ }^{19}$ In some experiments, NS398 (a specific COX-2 inhibitor) $20 \mu \mathrm{M}$ was included in the culture medium. After $18 \mathrm{~h}$ of culture, the cells were centrifuged $(400 \mathrm{~g})$ at $4^{\circ} \mathrm{C}$ for $5 \mathrm{~min}$; supernatants were stored at $-80^{\circ} \mathrm{C}$ for $\mathrm{PGE}_{2}$ and $\mathrm{TXB}_{2}$ concentration determination, and cell pellets were analyzed for Annexin $\mathrm{V}$ and intracellular COX-1-COX-2 staining.

Determination of $\mathrm{PGE}_{2}$ and $\mathrm{TXB}_{2}$ concentration in the culture supernatant

The concentration of $\mathrm{PGE}_{2}$ and $\mathrm{TXB}_{2}$ was measured by an enzyme immunoassay (EIA) (Cayman Chemical Co., Ann 
Arbor, MI, USA) according to the manufacturer's instructions. This assay is based on the competition between a $\mathrm{PGE}_{2}$ (or $\mathrm{TXB}_{2}$ ) and a $\mathrm{PGE}_{2}$ (or $\mathrm{TXB}_{2}$ )-acetylcholinesterase conjugate for a limited amount of $\mathrm{PGE}_{2}$ (or $\mathrm{TXB}_{2}$ ) monoclonal antibody. We measured $\mathrm{TXB}_{2}$ instead of $\mathrm{TXA}_{2}$, because the latter is rapidly hydrolyzed non-enzymically to a stable prostanoid $\mathrm{TXB}_{2}$. All samples were measured in duplicate. These EIA kits are very specific, with minimum cross-reactivity to non-targeted prostanoids. The detection limits for $\mathrm{PGE}_{2}$ and $\mathrm{TXB}_{2}$ are 15 and $45 \mathrm{pg} \mathrm{ml}^{-1}$, respectively. Calculations of the prostanoid concentrations were completed using software provided by Cayman.

\section{Determination of THP-1 cell viability}

Cell viability was assessed by counting the Annexin Vpositive (necrotic and apoptotic) cells. After the cells were washed with phosphate-buffered saline (PBS), they were incubated for $15 \mathrm{~min}$ with Annexin V-PE in Annexin Binding buffer (BD Pharmingen) at room temperature in the dark. The Annexin V-positive cells were detected using flow cytometry, and cell viability was determined by calculating the percentage of Annexin V-negative cells among all collected cells without gating.

\section{Intracellular staining of COX-1-COX-2}

Intracellular COX-1 and COX-2 were stained according to a previously described protocol. ${ }^{20}$ After the cells were washed with PBS, they were fixed and made permeable with Cytofix/Cytoperm (BD Pharmingen) for $20 \mathrm{~min}$ at room temperature. The permeable cells were washed with Perm/Wash (BD Pharmingen) and were incubated for 30 min with an anti-COX-1-FITC-anti-COX-2-PE antibody cocktail at $4{ }^{\circ} \mathrm{C}$ in the dark. The cells were then washed with the Perm/Wash and were subjected to flow cytometry. Isotype control antibodies were used to determine background fluorescence. The fluorescent intensity of COX in THP-1 cells was measured using a flow cytometer (BD LSR, BD Biosciences Immunocytometry Systems, CA, USA). The flow cytometer was equipped with a 488$\mathrm{nm}$ argon laser; the filter settings for FITC and PE were at 530 and at $585 \mathrm{~nm}$, respectively. At least 10,000 cells were collected for analysis. The amount of COX protein expression was estimated as the mean fluorescent intensity of COX-positive cells multiplied by the percentage of COX-positive cells.

COX activity determination in THP-1 cells

COX activity was determined according to previously reported studies. $^{21,22}$ THP-1 cells were stimulated with
LPS $1 \mu \mathrm{g} \mathrm{ml}^{-1}$ for $18 \mathrm{~h}$ to induce COX-2 protein expression, or they were left unstimulated. The cells were then washed three times with PBS. The cells $\left(5 \times 10^{6} / \mathrm{ml}\right)$ were then provided $\mathrm{AA} 10 \mu \mathrm{M}$ as a $\mathrm{COX}$ substrate and were incubated at $37^{\circ} \mathrm{C}$ in $5 \% \mathrm{CO}_{2}$ in RPMI complete medium in the absence (DMSO) or presence of propofol for $30 \mathrm{~min}$. Culture supernatants were collected and stored at $-80^{\circ} \mathrm{C}$ for measurement of $\mathrm{PGE}_{2}$ and $\mathrm{TXB}_{2}$. In some experiments, SC-560 (a non-selective COX inhibitor) $1 \mu \mathrm{M}$ or NS-398 (a selective COX-2 inhibitor) $20 \mu \mathrm{M}$ was included in the culture medium.

Statistical analysis

Results are expressed as means \pm SD. One-way analysis of variance with Bonferroni's correction was used for all comparisons. The data were analyzed using GraphPad Prism (GraphPad Software, Inc., San Diego, CA, USA), and a $P<0.05$ was considered statistically significant.

\section{Results}

Effects of propofol on $\mathrm{PGE}_{2}$ and $\mathrm{TXB}_{2}$ production by THP-1 cells

Without LPS stimulation, $\mathrm{PGE}_{2}$ and $\mathrm{TXB}_{2}$ production was low (Fig. 1). After stimulation, the concentration of both $\mathrm{PGE}_{2}$ and $\mathrm{TXB}_{2}$ increased dramatically; both were significantly decreased with the clinically pertinent concentrations of propofol. Although there was a small but significant decrease in viability of the THP-1 cells (decreased percentage of Annexin V-negative cells) after LPS treatment, propofol did not affect their viability to any significant extent.

\section{Effects of propofol on intracellular COX protein} expression

The expression of COX-1 protein was similar, irrespective of LPS stimulation or propofol treatment (Fig. 2). The THP-1 cells barely expressed COX-2 without LPS stimulation, whereas COX-2 protein levels were increased with stimulation, indicating the inducible nature of this enzyme. Clinically relevant concentrations of propofol did not alter LPS-induced COX-2 protein expression.

Effects of propofol on COX activity

In both LPS-untreated and LPS-treated cells, the eicosanoid production was very small without AA provision (Fig. 3). In LPS-untreated cells, provision of AA resulted in a significant increase in the production of $\mathrm{PGE}_{2}$, while 

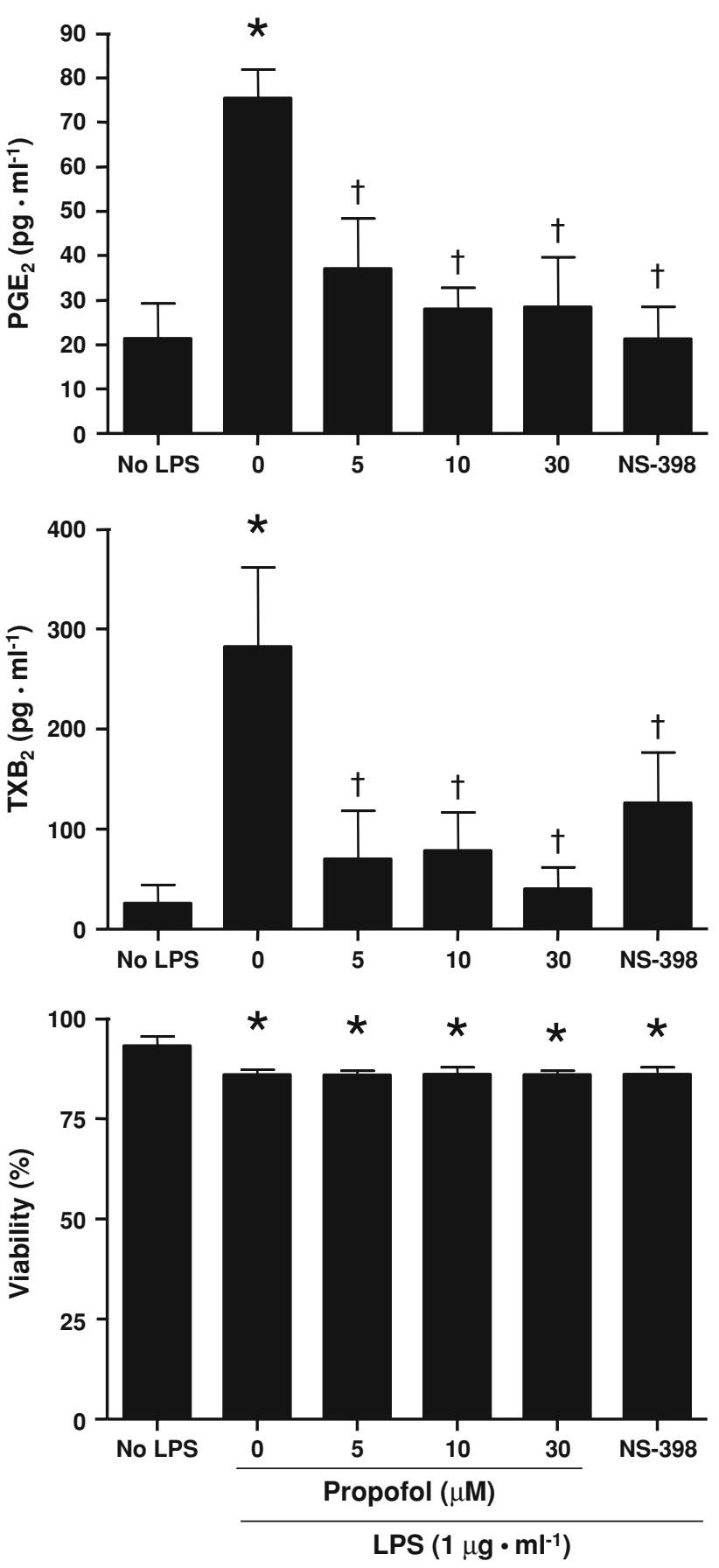

Fig. 1 Effects of propofol on prostaglandin $\mathrm{E}_{2}\left(\mathrm{PGE}_{2}\right)$ and thromboxane $\mathrm{B}_{2}\left(\mathrm{TXB}_{2}\right)$ production by THP-1 cells. Cells $\left(5 \times 10^{6} / \mathrm{ml}\right)$ were either stimulated with lipopolysaccharide (LPS; $1 \mu \mathrm{g} \mathrm{ml}^{-1}$ ) for $18 \mathrm{~h}$ or left unstimulated in the absence (DMSO) or presence of propofol. $\mathrm{PGE}_{2}$ and $\mathrm{TXB}_{2}$ production was measured by an enzyme immunoassay. Cell viability was assessed by calculating the percentage of Annexin V-negative cells using flow cytometry. In some experiments, NS-398 (a specific COX-2 inhibitor) $20 \mu \mathrm{M}$ was included in the culture medium. Data $(n=5)$ are expressed as means $\pm \mathrm{SD}, * P<0.001$ vs. No LPS. ${ }^{\dagger} P<0.001$ vs. propofol $0 \mu \mathrm{M}$ with LPS. There are no differences in concentrations of $\mathrm{PGE}_{2}$ and $\mathrm{TXB}_{2}$ between No LPS and propofol 5, 10, and $30 \mu \mathrm{M}$, and NS-398 such an increase was not noted with $\mathrm{TXB}_{2}$. In LPS-treated cells, both $\mathrm{PGE}_{2}$ and $\mathrm{TXB}_{2}$ production was significantly increased after provision of AA.

In LPS-untreated cells, there was a small but significant suppression of $\mathrm{PGE}_{2}$ production with propofol, whereas such propofol-induced suppression was not detected with $\mathrm{TXB}_{2}$. Treatment with SC-560, a non-selective COX inhibitor, suppressed the $\mathrm{PGE}_{2}$ production. In LPS-treated cells, propofol significantly suppressed both $\mathrm{PGE}_{2}$ and $\mathrm{TXB}_{2}$ production after provision of AA. After treatment with NS-398, a potent, highly selective-COX-2 inhibitor which halts the COX-2 activity, there remained very low levels of $\mathrm{PGE}_{2}$ and $\mathrm{TXB}_{2}$ production, which is due primarily to COX-1 activity.

\section{Discussion}

The main finding of the study revealed that propofol, in clinically relevant concentrations, inhibited prostanoid $\left(\mathrm{PGE}_{2}\right.$ and $\left.\mathrm{TXB}_{2}\right)$ production in human monocytic cell line THP-1. The study showed that the inhibitory effect was not due to cytotoxicity of propofol, because the proportion of Annexin V-positive cells (i.e., necrotic and apoptotic cells) did not increase with propofol.

The mechanism of propofol-induced inhibition of production of $\mathrm{PGE}_{2}$ and $\mathrm{TXB}_{2}$ was considered. Since both $\mathrm{PGE}_{2}$ and $\mathrm{TXB}_{2}$ production was suppressed, it is likely that the suppression is at the level of COX or upstream of COX. We first examined whether COX protein expression was suppressed by propofol, because propofol is reported to influence a number of signal transduction molecules that affect COX-2 expression. ${ }^{23-25}$ As shown in Fig. 2, propofol did not affect either COX-1 or COX-2 expression, precluding the possibility that the inhibitory effect of propofol on prostanoid production is via an inhibition of COX protein expression.

Another possible mechanism is that propofol suppresses the production of AA, the substrate of $\mathrm{COX}$. AA is produced from cell membrane via the action of $\mathrm{CPLA}_{2}$, the activity of which is affected by intracellular calcium concentrations and/or by the phosphorylation status of the enzyme induced by MAPKs, ${ }^{16-18}$ both of which are reported to be affected by propofol. $^{24-26}$ To circumvent the effect of AA availability, we provided THP-1 cells with a substrate of COX (i.e., AA) and measured the production of the end products of $\mathrm{COX}$ (i.e., $\mathrm{PGE}_{2}$ and $\mathrm{TXB}_{2}$ ). The results clearly showed that propofol suppressed the production of these prostanoids from activated THP-1 cells. Thus, it is concluded that propofol suppresses COX enzyme activity.

COX has two isoforms, COX-1 and COX-2. ${ }^{15} \mathrm{We}$ examined whether the propofol's inhibitory effect is 
A

No LPS

Propofol $0 \mu \mathrm{M}$

LPS

Propofol $0 \mu \mathrm{M}$

LPS

Propofol $30 \mu \mathrm{M}$
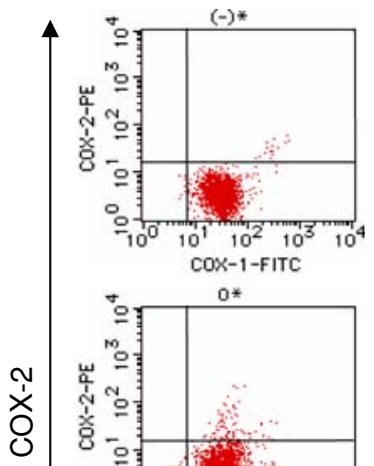

$0 *$

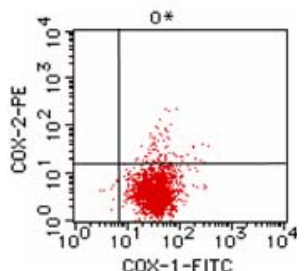

30 *

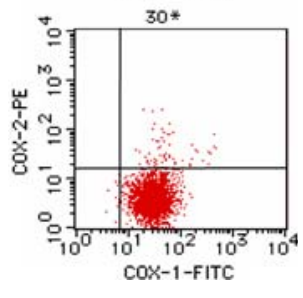

coX-1
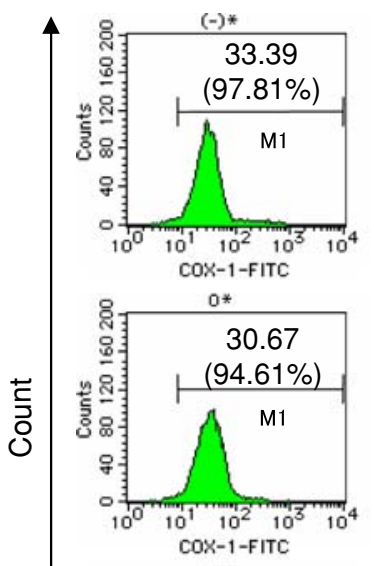

$30 *$

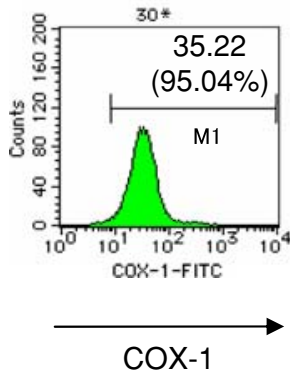

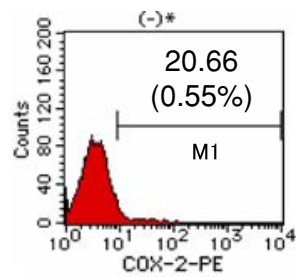

$0 *$

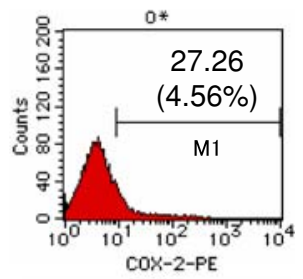

$30 *$

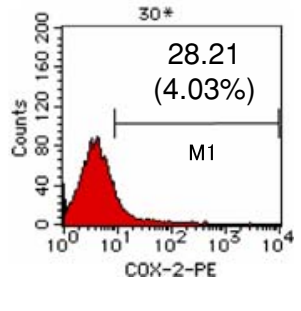

cox-2

B $P=0.056$

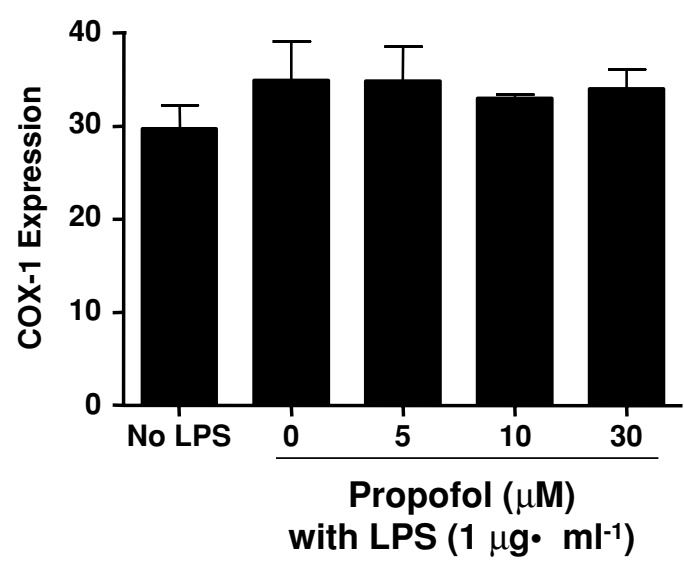

Fig. 2 Effects of propofol on intracellular cyclo-oxygenase (COX) protein expression. THP-1 cells $\left(5 \times 10^{6} / \mathrm{ml}\right)$ were stimulated with lipopolysaccharide (LPS; $1 \mu \mathrm{g} \mathrm{ml}^{-1}$ ) for $18 \mathrm{~h}$ or left unstimulated in the absence (DMSO) or presence of propofol. a The mean fluorescent intensities of COX-positive cells are shown with the percentages of

isoform-specific. Without LPS stimulation, COX-2 protein was barely detected in THP-1 cells, an outcome reported in a previous study with this cell line. ${ }^{27}$ Therefore, it is expected that the activity of COX measured with LPSuntreated cells is that of COX-1. On the other hand, COX-2 expression was induced by $18 \mathrm{~h}$ of LPS stimulation. Thus, the activity measured in LPS-pretreated cells is expected to be that of COX-2 and, to a lesser extent, COX-1. The fact that propofol decreased $\mathrm{PGE}_{2}$ and $\mathrm{TXB}_{2}$ concentrations to similar levels as those obtained in the absence of COX-2

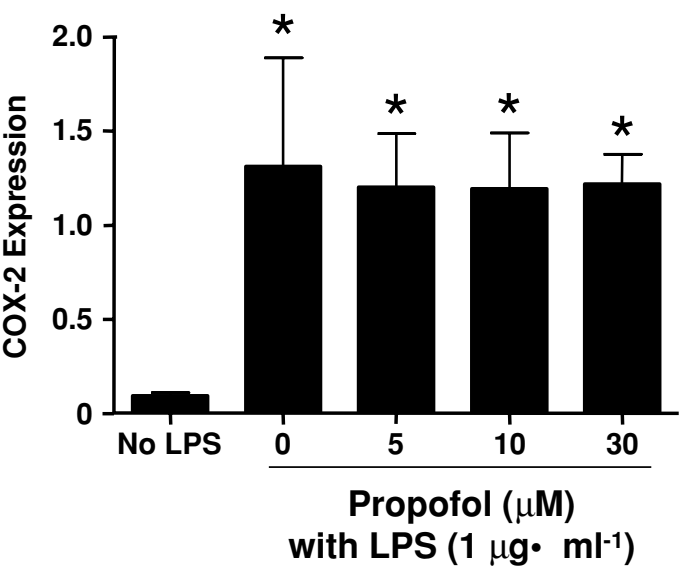

COX-positive cells in parentheses. $\mathbf{b}$ The expression of COX protein [(mean fluorescent intensity of COX-positive cells) $\times$ (percentage of COX-positive cells)]. Data $(n=5)$ are expressed as means $\pm \mathrm{SD}$, $* P<0.001$ vs. No LPS

activity (which resulted after COX-2 activity was halted by NS-398, a potent and highly selective COX-2 inhibitor) (Fig. 3), may indicate that propofol has a potent COX-2 inhibiting activity. We found a small but significant decrease of $\mathrm{PGE}_{2}$ production from LPS-untreated THP-1 cells with propofol, indicating that propofol may also have a small COX-1 inhibiting effect. In the present study, however, AA failed to induce a production of $\mathrm{TXB}_{2}$ in LPS-untreated cells, which precluded the assessment of the effect of propofol on COX-1 using $\mathrm{TXB}_{2}$. The reason that 

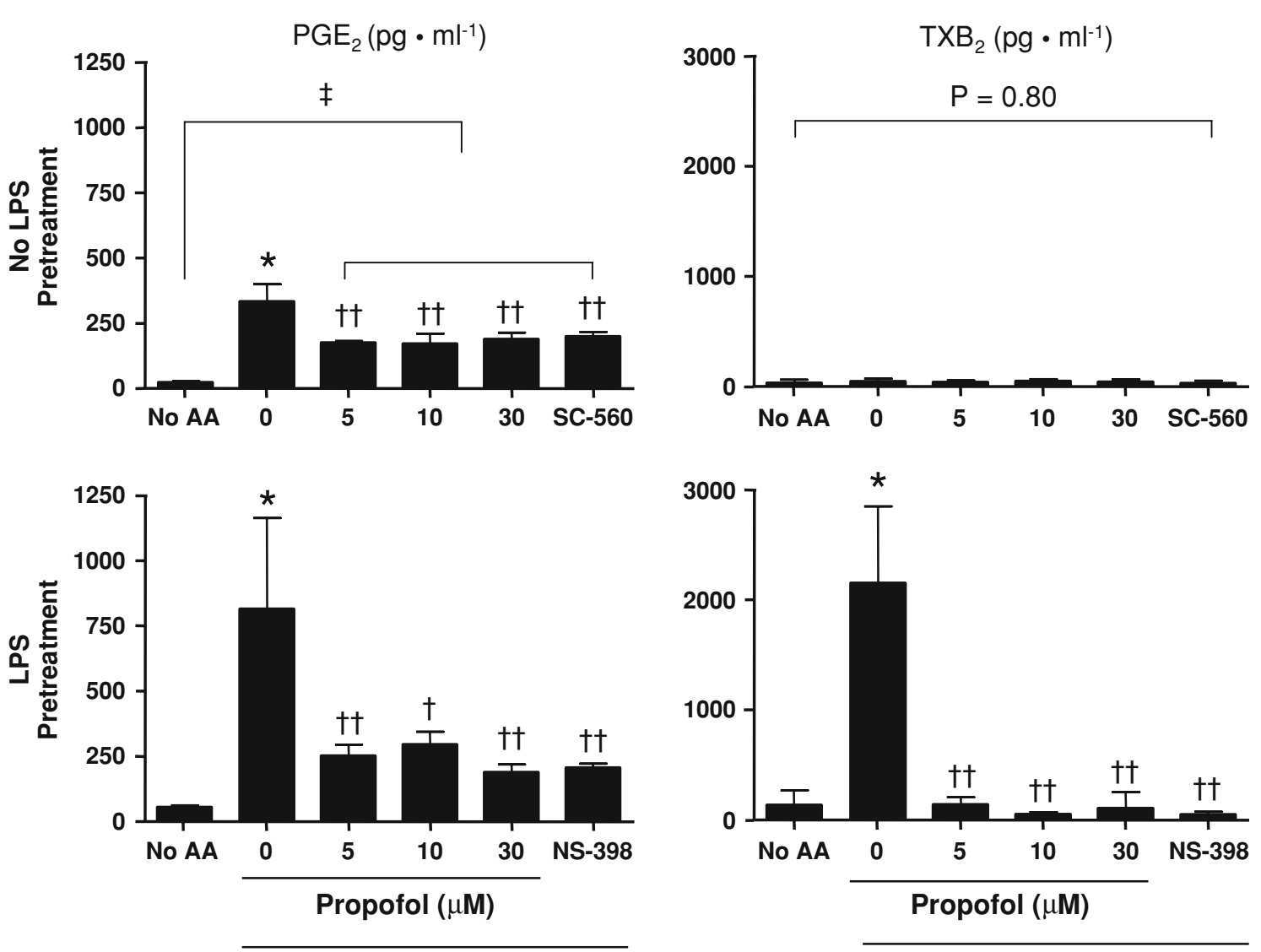

AA $(10 \mu \mathrm{M})$

Fig. 3 Effects of propofol on cyclo-oxygenase (COX) activity in THP-1 cells. THP-1 cells were stimulated with lipopolysaccharide (LPS; $1 \mu \mathrm{g} \mathrm{ml}^{-1}$ ) for $18 \mathrm{~h}$ or left unstimulated. Cells were then washed three times with phosphate-buffered saline. The cells $\left(5 \times 10^{6} / \mathrm{ml}\right)$ were then stimulated with arachidonic acid (AA) $10 \mu \mathrm{M}$ for $30 \mathrm{~min}$ at $37^{\circ} \mathrm{C}$ in the absence (DMSO) or presence of propofol, and supernatants were analyzed for prostaglandin $\mathrm{E}_{2}\left(\mathrm{PGE}_{2}\right)$

AA provoked a production of $\mathrm{PGE}_{2}$, but not $\mathrm{TXB}_{2}$, in LPSuntreated cells is unknown. Perhaps it is due to the difference in enzyme affinity between PGES and TXS for limited availability for their substrate $\mathrm{PGH}_{2}{ }^{28}$

The concentrations of $\mathrm{PGE}_{2}$ and $\mathrm{TXB}_{2}$ secreted from THP-1 cells (with and without LPS stimulation) were similar to those measured in previous studies. ${ }^{29,30}$ THP-1 had a constitutive expression of COX-1 protein in the present study, similar to a previous study using Western blotting. ${ }^{27}$ With regard to COX-2 protein expression in THP-1 cells, it is reported to be induced by LPS stimulation and to be absent without LPS stimulation. ${ }^{27}$ Our study also showed the inducible nature of COX-2 enzyme using flow cytometry. However, unlike the previous study using Western blot, where there is no COX-2 expression without LPS stimulation, ${ }^{27}$ there was a distinct (but very low) expression of COX-2 in the present study. We assume that this low expression is the artifact background rather than a true expression and may presumably be due to the $\mathrm{Fc} \gamma$

and thromboxane $\mathrm{B}_{2}\left(\mathrm{TXB}_{2}\right)$. In some experiments, SC-560 (a nonselective COX inhibitor) $1 \mu \mathrm{M}$ or NS-398 (a selective COX-2 inhibitor) $20 \mu \mathrm{M}$ was included in the culture medium. Data $(n=4)$ are expressed as means \pm SD. $* P<0.001$ vs. No AA, ${ }^{\dagger} P<0.01,{ }^{\dagger}$ $P<0.001$ vs. propofol $0 \mu \mathrm{M},{ }^{\star} P<0.001$ between No AA and propofol 5, 10, and $30 \mu \mathrm{M}$, and SC-560

receptor-mediated non-specific binding of anti-COX-2 antibody. ${ }^{31}$

We tested the following concentrations of propofol; $5 \mu \mathrm{M}\left(0.9 \mu \mathrm{g} \mathrm{ml}^{-1}\right), 10 \mu \mathrm{M}\left(1.8 \mu \mathrm{g} \mathrm{ml}^{-1}\right)$, and $30 \mu \mathrm{M}$ $\left(5.3 \mu \mathrm{g} \mathrm{ml}^{-1}\right)$. A previous study showed that the plasma concentrations of propofol for moderate sedation (no anxiety, strong relaxation, slow response to painful stimulation) and for deep sedation (strong sleepiness, slurred speech, slow or no response to painful stimulation) are $0.5 \pm 0.2$ and $1.4 \pm 0.6 \mu \mathrm{g} \mathrm{ml}^{-1}$, respectively. ${ }^{19}$ Therefore, the 5, 10, and $30 \mu \mathrm{M}$ concentrations of propofol may correspond to the plasma concentrations achieved during moderate sedation, deep sedation, and anesthesia, ${ }^{32}$ respectively.

What are the clinical implications of inhibiting COX activity with propofol in the monocytic cell line THP-1? Since prostanoids can promote inflammation, ${ }^{14,33}$ propofol, via its inhibition of prostanoid production, could be an antiinflammatory anesthetic. ${ }^{14}$ However, in selected cases, 
prostanoids are also reported to inhibit inflammation via the regulation of the actions of cytokines that initiate the inflammatory cascade. ${ }^{14,33,34}$ Thus, it may be more appropriate to state that propofol can modulate inflammation via the suppression of COX activity.

$\mathrm{TXA}_{2}$ is a pro-coagulant, and increased production of $\mathrm{TXA}_{2}$ from monocytes-macrophages in response to AA is implicated in the enhanced thrombosis and vascular injury in diabetic patients. ${ }^{35}$ Decreased $\mathrm{TXA}_{2}$ production with propofol might be beneficial during the perioperative period when heightened coagulation may become a problem. ${ }^{36}$ $\mathrm{PGE}_{2}$ reportedly influences immune responses. ${ }^{37-41}$ For example, $\mathrm{PGE}_{2}$ has been shown to cause immunosuppression by inhibiting LPS-induced interleukin (IL)-12 production by monocytes, decreasing the IL-2-driven proliferation of $\mathrm{T}$ cells, and/or suppressing interferon- $\gamma$ production by natural killer cells and T cells. ${ }^{37-41}$ Therefore, it is possible that propofol, via inhibition of COX-2 activity and $\mathrm{PGE}_{2}$ production, mitigates immunosuppression frequently seen in patients during the perioperative period. ${ }^{4,5}$ However, these possibilities should be validated in patients undergoing the long-term use of propofol for sedation.

One likely reason for the decreased prostanoid production by activated THP-1 cells with propofol is the inhibition of COX activity; however, other possibilities, such as the deprivation of COX substrate by propofol, cannot be ruled out in the present study. The fact that we used the human monocytic cell line rather than human monocytes is another limitation of the study. Cell lines have mutations and their physiology may differ from normal cells. Further research with human monocytes will be needed.

In summary, we have reported that propofol inhibited prostanoid production in the human monocytic cell line THP-1. Previous studies indicated that the well-known anti-oxidant properties of propofol might be related to its chemical structure, which is similar to that of phenol-based scavengers such as tocopherols. ${ }^{1,9,42-44}$ Indeed, $\alpha$-tocopherol is reported to have a strong anti-oxidizing effect. ${ }^{42}$ Similarly, propofol's inhibitory effect on COX might be ascribable to its structural similarity to $\gamma$-tocopherol. It has been reported that $\gamma$-tocopherol has a COX-2 inhibiting effect in macrophages. ${ }^{44}$

Acknowledgment This study was supported by institutional departmental sources.

Conflicts of interest None declared.

\section{References}

1. Vanlersberghe C, Сати F. Propofol. Handb Exp Pharmacol 2008; 182: 227-52.
2. Helmy SA, Al-Attiyah RJ. The immunomodulatory effects of prolonged intravenous infusion of propofol versus midazolam in critically ill surgical patients. Anaesthesia 2001; 56: 4-8.

3. De Cosmo G, Congedo E, Clemente A, Aceto P. Sedation in PACU: the role of propofol. Curr Drug Targets 2005; 6: 741-4.

4. Slade MS, Simmons RL, Yunis E, Greenberg LJ. Immunodepression after major surgery in normal patients. Surgery 1975; 78 : 363-72.

5. Walton $B$. Effects of anaesthesia and surgery on immune status. Br J Anaesth 1979; 51: 37-43.

6. Mak TW, Saunders ME. The Immune Response: Basic and Clinical Principles, 1st ed. Burlington, USA: Elsevier Academic Press; 2006.

7. Chen RM, Wu GJ, Tai YT, et al. Propofol reduces nitric oxide biosynthesis in lipopolysaccharide-activated macrophages by downregulating the expression of inducible nitric oxide synthase. Arch Toxicol 2003; 77: 418-23.

8. Gonzalez-Correa JA, Cruz-Andreotti E, Arrebola MM, LopezVillodres JA, Jodar M, De La Cruz JP. Effects of propofol on the leukocyte nitric oxide pathway: in vitro and ex vivo studies in surgical patients. Naunyn Schmiedebergs Arch Pharmacol 2008; 376: 331-9.

9. Chen $R M$, Chen $T G$, Chen $T L$, et al. Anti-inflammatory and antioxidative effects of propofol on lipopolysaccharide-activated macrophages. Ann NY Acad Sci 2005; 1042: 262-71.

10. Marik PE. Propofol: an immunomodulating agent. Pharmacotherapy 2005; 25: 28S-33S.

11. Salo M, Pirttikangas CO, Pulkki K. Effects of propofol emulsion and thiopentone on $\mathrm{T}$ helper cell type-1/type-2 balance in vitro. Anaesthesia 1997; 52: 341-4.

12. Ghosh DK, Misukonis MA, Reich C, Pisetsky DS, Weinberg JB. Host response to infection: the role of CpG DNA in induction of cyclooxygenase 2 and nitric oxide synthase 2 in murine macrophages. Infect Immun 2001; 69: 7703-10.

13. Kolaczkowska E, Shahzidi S, Seljelid R, van Rooijen N, Plytycz B. Early vascular permeability in murine experimental peritonitis is co-mediated by resident peritoneal macrophages and mast cells: crucial involvement of macrophage-derived cysteinyl-leukotrienes. Inflammation 2002; 26: 61-71.

14. Tilley SL, Coffman TM, Koller BH. Mixed messages: modulation of inflammation and immune responses by prostaglandins and thromboxanes. J Clin Invest 2001; 108: 15-23.

15. Simmons DL, Botting RM, Hla T. Cyclooxygenase isozymes: the biology of prostaglandin synthesis and inhibition. Pharmacol Rev 2004; 56: 387-437.

16. Rehfeldt W, Resch K, Goppelt-Struebe M. Cytosolic phospholipase A2 from human monocytic cells: characterization of substrate specificity and $\mathrm{Ca}(2+)$-dependent membrane association. Biochem J 1993; 293(Pt 1): 255-61.

17. Jiang YJ, Lu B, Choy PC, Hatch GM. Regulation of cytosolic phospholipase A2, cyclooxygenase-1 and -2 expression by PMA, TNF-alpha, LPS and M-CSF in human monocytes and macrophages. Mol Cell Biochem 2003; 246: 31-8.

18. Hazan-Halevy I, Levy T, Wolak T, Lubarsky I, Levy R, Paran E. Stimulation of NADPH oxidase by angiotensin II in human neutrophils is mediated by ERK p38 MAP-kinase and cytosolic phospholipase A2. J Hypertens 2005; 23: 1183-90.

19. Matsuki Y, Ichinohe T, Kaneko Y. Amnesia for electric dental pulp stimulation and picture recall test under different levels of propofol or midazolam sedation. Acta Anaesthesiol Scand 2007; 51: 16-21.

20. Ruitenberg JJ, Waters CA. A rapid flow cytometric method for the detection of intracellular cyclooxygenases in human whole blood monocytes and a COX-2 inducible human cell line. J Immunol Methods 2003; 274: 93-104. 
21. Demasi M, Caughey GE, James MJ, Cleland LG. Assay of cyclooxygenase-1 and 2 in human monocytes. Inflamm Res 2000; 49: $737-43$.

22. St-Onge M, Flamand N, Biarc J, et al. Characterization of prostaglandin E2 generation through the cyclooxygenase (COX)-2 pathway in human neutrophils. Biochim Biophys Acta 2007; 1771: 1235-45.

23. Mestre JR, Mackrell PJ, Rivadeneira DE, Stapleton PP, Tanabe $T$, Daly $J M$. Redundancy in the signaling pathways and promoter elements regulating cyclooxygenase- 2 gene expression in endotoxin-treated macrophage/monocytic cells. J Biol Chem 2001; 276: $3977-82$.

24. Jawan B, Kao YH, Goto S, et al. Propofol pretreatment attenuates LPS-induced granulocyte-macrophage colony-stimulating factor production in cultured hepatocytes by suppressing MAPK/ERK activity and NF-kappaB translocation. Toxicol Appl Pharmacol 2008; 229: 362-73.

25. Wu XJ, Zheng YJ, Cui YY, Zhu L, Lu Y, Chen HZ. Propofol attenuates oxidative stress-induced $\mathrm{PC} 12$ cell injury via p38 MAP kinase dependent pathway. Acta Pharmacol Sin 2007; 28 : 1123-8.

26. Yun JY, Park KS, Kim JH, Do SH, Zuo Z. Propofol reverses oxidative stress-attenuated glutamate transporter EAAT3 activity: evidence of protein kinase C involvement. Eur J Pharmacol 2007; 565: 83-8.

27. Wu SJ, Liu PL, Ng LT. Tocotrienol-rich fraction of palm oil exhibits anti-inflammatory property by suppressing the expression of inflammatory mediators in human monocytic cells. Mol Nutr Food Res 2008; 52: 921-9.

28. Penglis PS, Cleland LG, Demasi M, Caughey GE, James MJ. Differential regulation of prostaglandin E2 and thromboxane A2 production in human monocytes: implications for the use of cyclooxygenase inhibitors. J Immunol 2000; 165: 1605-11.

29. Jun HK, Lee HR, Lee SH, Choi BK. Mapping of the proinflammatory domains of MspTL of Treponema lecithinolyticum. Microbiology 2007; 153: 2386-92.

30. Durando MM, Meier KE, Cook JA. Endotoxin activation of mitogen-activated protein kinase in THP-1 cells; diminished activation following endotoxin desensitization. J Leukoc Biol 1998; 64: 259-64.

31. Boltz-Nitulescu G, Willheim M, Spittler A, Leutmezer F, Tempfer $C$, Winkler $S$. Modulation of $\mathrm{IgA}$, IgE, and $\mathrm{IgG} \mathrm{Fc}$ receptor expression on human mononuclear phagocytes by 1 alpha, 25dihydroxyvitamin D3 and cytokines. J Leukoc Biol 1995; 58: 256-62.
32. Rigouzzo A, Girault L, Louvet N, et al. The relationship between bispectral index and propofol during target-controlled infusion anesthesia: a comparative study between children and young adults. Anesth Analg 2008; 106: 1109-16.

33. James MJ, Penglis PS, Caughey GE, Demasi M, Cleland LG. Eicosanoid production by human monocytes: does COX-2 contribute to a self-limiting inflammatory response? Inflamm Res 2001; 50: 249-53.

34. Demeure CE, Yang LP, Desjardins C, Raynauld P, Delespesse G. Prostaglandin E2 primes naive $T$ cells for the production of antiinflammatory cytokines. Eur J Immunol 1997; 27: 3526-31.

35. Konieczkowski M, Skrinska VA. Increased synthesis of thromboxane A2 and expression of procoagulant activity by monocytes in response to arachidonic acid in diabetes mellitus. Prostaglandins Leukot Essent Fatty Acids 2001; 65: 133-8.

36. Rawat A, Huynh TT, Peden EK, Kougias P, Lin PH. Primary prophylaxis of venous thromboembolism in surgical patients. Vasc Endovascular Surg 2008; 42: 205-16.

37. Harris SG, Padilla J, Koumas L, Ray D, Phipps RP. Prostaglandins as modulators of immunity. Trends Immunol 2002; 23: 144-50.

38. Harizi H, Juzan M, Pitard V, Moreau JF, Gualde N. Cyclooxygenase-2-issued prostaglandin E2 enhances the production of endogenous IL-10, which down-regulates dendritic cell functions. J Immunol 2002; 168: 2255-63.

39. van der Pouw Kraan TC, Boeije LC, Smeenk RJ, Wijdenes J, Aarden LA. Prostaglandin-E2 is a potent inhibitor of human interleukin 12 production. J Exp Med 1995; 181: 775-9.

40. Pockaj BA, Basu GD, Pathangey LB, et al. Reduced T-cell and dendritic cell function is related to cyclooxygenase- 2 overexpression and prostaglandin E2 secretion in patients with breast cancer. Ann Surg Oncol 2004; 11: 328-39.

41. Walker W, Rotondo D. Prostaglandin E2 is a potent regulator of interleukin-12- and interleukin-18-induced natural killer cell interferon-gamma synthesis. Immunology 2004; 111: 298-305.

42. Aarts L, van der Hee R, Dekker I, de Jong J, Langemeijer H, Bast $A$. The widely used anesthetic agent propofol can replace alphatocopherol as an antioxidant. FEBS Lett 1995; 357: 83-5.

43. Ansley DM, Lee J, Godin DV, Garnett ME, Qayumi AK. Propofol enhances red cell antioxidant capacity in swine and humans. Can J Anaesth 1998; 45: 233-9.

44. Jiang Q, Elson-Schwab I, Courtemanche C, Ames BN. Gammatocopherol and its major metabolite, in contrast to alpha-tocopherol, inhibit cyclooxygenase activity in macrophages and epithelial cells. Proc Natl Acad Sci USA 2000; 97: 11494-9. 